$\$$ Research Square

\section{Necrolytic migratory erythema: an important visual cutaneous clue of glucagonoma}

\section{Wei Li}

First Affiliated Hospital of Xi'an Jiaotong University

Xue Yang

First Affiliated Hospital of Xi'an Jiaotong University

Yuan Deng

First Affiliated Hospital of Xi'an Jiaotong University

Yina Jiang

First Affiliated Hospital of Xi'an Jiaotong University

\section{Guiping Xu}

First Affiliated Hospital of Xi'an Jiaotong University

\section{Enxiao Li}

First Affiliated Hospital of Xi'an Jiaotong University

\section{Yinying Wu}

First Affiliated Hospital of Xi'an Jiaotong University

Juan Ren

First Affiliated Hospital of Xi'an Jiaotong University

Zhenhua Ma

First Affiliated Hospital of Xi'an Jiaotong University

\section{Shunbin Dong}

First Affiliated Hospital of Xi'an Jiaotong University

\section{Liang Han}

First Affiliated Hospital of Xi'an Jiaotong University

\section{Zheng Wu}

First Affiliated Hospital of Xi'an Jiaotong University

Zheng Wang ( $\square$ wangzhengxjtu@163.com )

First Affiliated Hospital of Xi'an Jiaotong University

\section{Research Article}

Keywords: glucagonoma, necrolytic migratory erythema, diagnosis, treatment

Posted Date: January 13th, 2022

DOI: https://doi.org/10.21203/rs.3.rs-1225300/v1

License: (c) (7) This work is licensed under a Creative Commons Attribution 4.0 International License. Read Full License 


\section{Abstract}

Objective: Glucagonoma is an extremely rare neuroendocrine tumor that arises from pancreatic islet alpha cells. Although glucagonoma is usually accompanied by a variety of characteristic clinical symptoms, early diagnosis is still difficult due to the scarcity of the disease.

Methods: In this study, we present the cumulative experiences, clinical characteristics and treatments of seven patients diagnosed with glucagonoma during the past 10 years at the First Affiliated Hospital of Xi'an Jiaotong University.

Results: The seven patients in our cohort consisted of six females and one male with an average diagnosis age of 40.1 years (range 23-51). The average time from onset of symptoms to diagnosis of glucagonoma was 14 months (range 2-36 months). All the patients visited dermatology firstly for necrolytic migratory erythema (NME) 7/7 (100\%), other presenting symptoms included: diabetes mellitus (DM) 4/7 (57\%), stomatitis 2/7 (28\%), weight loss 4/7 (57\%), anemia 4/7 (57\%), diarrhea 1/7 (14\%), DVT1/7 (14\%). Plasma glucagon levels were increased in all patients (range 216.92-3155 pg/mL), and declined after surgery. Imaging studies revealed that four of seven patients had liver metastasis. Six of seven patients received surgical resection, and all of them received somatostatin analogue therapy. Symptoms improved significantly in 6 out of 7 patients. Three of seven patients died of this disease by the time of follow-up.

Conclusion: Our data suggest that if persistent NME is associated with DM and high glucagon levels, timely abdominal imaging should be performed to confirm glucagonoma. Once diagnosed, surgery and somatostatin analogues are effective for symptom relief and tumor control.

\section{Introduction}

Glucagonoma is an extremely rare and slow-growing functional pancreatic neuroendocrine tumor arising from islet alpha cells in the tail of the pancreas. It usually presents with glucagonoma syndrome associated with characteristic clinical symptoms including necrolytic migratory erythema (NME), diabetes mellitus (DM), stomatitis, anemia, deep vein thrombosis (DVT), weight loss, diarrhea and other symptoms[1]. With the exception of NME, other clinical manifestations are non-specific, which accounts for the delay in diagnosis in most cases and also for the fact that at least $50 \%$ of cases already have metastatic disease at the time of diagnosis.

NME is observed in about $70 \%-90 \%$ of patients diagnosed with glucagonoma[2-3].This rash is usually widespread and the major sites of involvement are the perioral region, trunk, extremities and perineum[4-5]. The distinguishing feature of NME contain annular erythematous plaques with central bullous, ulcerative lesions surrounded by brown pigment, which are usually pruritic and painful[5-6]. The histological features of this skin lesion include parakeratosis, hyperkeratosis, spongiosis of the epidermis with necrolysis, loss of the granular layer, vacuolization of keratinocytes, perivascular and interstitial inflammation[7].

This paper summarizes the clinical characteristics of seven typical patients with glucagonoma followed at our hospital during the past 10 years. Our cumulative experiences (including diagnosis and treatment) may help clinicians to better recognize, diagnose and treat glucagonoma.

\section{Patients And Methods}

This study has been approved by the Ethics Committee of the First Affiliated Hospital of Xi'an Jiaotong University, and the study was conducted in accordance with the approved guidelines. The informed consent was obtained from all subjects and/or their legal guardian(s). We reviewed the database and collected seven cases of glucagonoma in the past 10 years. Patients with clinical presentations of glucagonoma syndrome, elevated plasma glucagon, and a pathological diagnosis of pancreatic islet cell tumor were included in this cohort. The medical records of the included patients were reviewed. Tumour diameters were obtained from CT scan measurements. Follow-up data, including patients' follow-up status and administration of other therapies, were acquired from hospital medical records or by phone interviews with the patients, relatives, or general practitioners.

\section{Results}

\section{Case Presentation}

The seven patients consisted of six females and one male, and the median age at diagnosis was 40.1 years (range 23-51) (Table 1). The duration from initial symptom presentation to final diagnosis ranged from 2 months to 3 years (Table 1). The most common symptoms of all the seven the patients with glucagonoma in the present study are presented in Table 1. 
Table 1

Patient presentation, tumor Characteristics and treatments.

\begin{tabular}{|c|c|c|c|c|c|c|c|}
\hline Patient & 1 & 2 & 3 & 4 & 5 & 6 & 7 \\
\hline Male/female & $\mathrm{F}$ & $\mathrm{F}$ & $\mathrm{F}$ & $\mathrm{F}$ & $\mathrm{F}$ & $\mathrm{F}$ & $M$ \\
\hline $\begin{array}{l}\text { Age at } \\
\text { diagnosis } \\
\text { (years) }\end{array}$ & 25 & 44 & 47 & 49 & 51 & 23 & 42 \\
\hline \multicolumn{8}{|l|}{$\begin{array}{l}\text { Symptoms at } \\
\text { diagnosis }\end{array}$} \\
\hline NME & $\mathrm{Y}$ & $Y$ & $\mathrm{Y}$ & $\mathrm{Y}$ & $Y$ & $\mathrm{Y}$ & $\mathrm{Y}$ \\
\hline Diabetes & $\begin{array}{l}\text { N (but with } \\
\text { IGT) }\end{array}$ & $\begin{array}{l}\mathrm{N} \text { (but with } \\
\text { IGT) }\end{array}$ & $Y$ & $\mathrm{Y}$ & Y & $\mathrm{Y}$ & $\mathrm{Y}$ \\
\hline \multicolumn{8}{|l|}{$\begin{array}{l}\text { cheilitis } \\
\text { included) }\end{array}$} \\
\hline Weight loss & $\mathrm{N}$ & $\mathrm{N}$ & $\mathrm{Y}$ & $\mathrm{Y}$ & $\mathrm{Y}$ & $\mathrm{N}$ & $\mathrm{Y}$ \\
\hline Anemia & $\mathrm{N}$ & $\mathrm{N}$ & $Y$ & Y & $Y$ & $\mathrm{Y}$ & $\mathrm{N}$ \\
\hline Diarrhea & $\mathrm{N}$ & $\mathrm{N}$ & $\mathrm{Y}$ & $\mathrm{N}$ & $\mathrm{N}$ & $\mathrm{N}$ & $\mathrm{N}$ \\
\hline DVT & $\mathrm{N}$ & $\mathrm{N}$ & $\mathrm{N}$ & $\mathrm{Y}$ & $\mathrm{N}$ & $\mathrm{N}$ & $\mathrm{N}$ \\
\hline $\begin{array}{l}\text { The first } \\
\text { department } \\
\text { visited }\end{array}$ & Dermatology & Dermatology & Dermatology & Dermatology & Dermatology & Dermatology & Dermatology \\
\hline \multicolumn{8}{|l|}{$\begin{array}{l}\text { Biochemical } \\
\text { diagnosis and }\end{array}$} \\
\hline $\begin{array}{l}\text { Was skin } \\
\text { biopsy } \\
\text { diagnostic? }\end{array}$ & Y & Y & $Y$ & $\mathrm{Y}$ & $Y$ & $\mathrm{Y}$ & $Y$ \\
\hline $\begin{array}{l}\text { Plasma } \\
\text { glucagon } \\
\text { (pg/mL) }\end{array}$ & 217 & 720 & 3155 & 1720 & 920 & $>800$ & 269 \\
\hline $\begin{array}{l}\text { Glucagon } \\
\text { immunostain }\end{array}$ & + & + & ND & + & + & + & + \\
\hline \multirow[t]{2}{*}{ Ki-67 } & $8 \%$ & $10 \%$ & $10 \%$ & NA & 1. $1 \%$ & $30 \%$ & $8 \%$ \\
\hline & & & & & $2.8 \%$ & & \\
\hline \multirow[t]{2}{*}{$\mathrm{CgA}(\mathrm{ng} / \mathrm{mL})$} & + & + & ND & + & 1. - & + & + \\
\hline & & & & & 2. + & & \\
\hline NSE (ng/mL) & 43.05 & + & 29.65 & + & 19.54 & Normal & + \\
\hline \multirow[t]{2}{*}{ SSTR2 } & + & - & ND & - & 1. - & + & + \\
\hline & & & & & 2. \pm & & \\
\hline \multirow{2}{*}{$\begin{array}{l}\text { Gastrin } \\
(\mathrm{pg} / \mathrm{mL})\end{array}$} & ND & - & ND & - & 1. - & - & - \\
\hline & & & & & 2. \pm & & \\
\hline \multirow[t]{2}{*}{ Syn } & + & + & ND & + & 1. - & + & + \\
\hline & & & & & 2. + & & \\
\hline
\end{tabular}

Normal glucagon levels $<200 \mathrm{pg} / \mathrm{mL}$. NME, necrotizing migratory erythema; DVT, deep vein thrombosis; IGT, impaired glucose tolerance; RPPPD, robotassisted pylorus-preserving pancreaticoduodenectomy; DP, distal pancreatectomy; PD, pancreaticoduodenectomy; TACE, transarterial chemoembolization; PRRT, peptide receptor radioligand therapy; RFA, radiofrequency ablation N, no; Y, yes; ND, not done; NA, not available. 


\begin{tabular}{|c|c|c|c|c|c|c|c|}
\hline Patient & 1 & 2 & 3 & 4 & 5 & 6 & 7 \\
\hline ESR & ND & ND & ND & ND & ND & ND & ND \\
\hline $\begin{array}{l}\text { Time from } \\
\text { symptoms to } \\
\text { diagnosis } \\
\text { (months) }\end{array}$ & 8 & 3 & 2 & 24 & 12 & 14 & 36 \\
\hline $\begin{array}{l}\text { Pancreatic } \\
\text { tumor location }\end{array}$ & Head & Head & Tail & Tail & Body and tail & Head & Head \\
\hline $\begin{array}{l}\text { Tumor size } \\
(\mathrm{cm})\end{array}$ & $3.1 \times 2.3 \times 1.6$ & $3.5 \times 2.1 \times 2.0$ & $2.3 \times 2.0 \times 2.0$ & $8.0 \times 5.0 \times 3.5$ & $6.5 \times 5.0 \times 4.5$ & $4.2 \times 6.0 \times 5.0$ & $4.2 \times 5.0 \times 4.7$ \\
\hline $\begin{array}{l}\text { Location of } \\
\text { metastasis }\end{array}$ & N & $\mathrm{N}$ & Liver & $\begin{array}{l}\text { Liver, lymph } \\
\text { nodes }\end{array}$ & $\begin{array}{l}\text { Liver, lymph } \\
\text { nodes }\end{array}$ & Liver & $\mathrm{N}$ \\
\hline TNM staging & $\begin{array}{l}\text { lla (T2, N0, } \\
\text { M0) }\end{array}$ & $\begin{array}{l}\text { Ila (T2, } \\
\text { NO,M0) }\end{array}$ & $\begin{array}{l}\text { IV (T2, Nx, } \\
\text { M1) }\end{array}$ & IV (T3, N1, M1) & IV (T3, N1, M1) & IV (T3, N0, M1) & $\begin{array}{l}\text { Ilb (T3, N0, } \\
\text { M0) }\end{array}$ \\
\hline Surgery & R-PPPD & PD & ND & DP+splenectomy & $\begin{array}{l}\text { 1. LDP + } \\
\text { splenectomy + } \\
\text { liver nodule } \\
\text { biopsy } \\
\text { resection } \\
\text { 2. Open } \\
\text { exploration+ } \\
\text { adhesionolysis } \\
+ \\
\text { pancreatectomy }\end{array}$ & $\begin{array}{l}\text { PD+ hepatic } \\
\text { metastasectomy }\end{array}$ & $\mathrm{PD}$ \\
\hline $\begin{array}{l}\text { Somatostatin } \\
\text { analogue }\end{array}$ & $\begin{array}{l}\text { Octreotide } \\
\text { LAR } \\
30 \\
\mathrm{mg} \times 1 / \text { month }\end{array}$ & $\begin{array}{l}\text { Octreotide } \\
100 \\
\mu g \times 3 / \text { day }\end{array}$ & $\begin{array}{l}\text { Octreotide } \\
\text { LAR } \\
30 \\
\mathrm{mg} \times 1 / \text { month }\end{array}$ & $\begin{array}{l}\text { Octreotide } \\
600 \mu \mathrm{g} / \text { day }\end{array}$ & $\begin{array}{l}\text { Octreotide LAR } \\
30 \\
\text { mg } \times 1 / \text { month }\end{array}$ & $\begin{array}{l}\text { Octreotide LAR } \\
30 \mathrm{mg} \times 1 / \text { month }\end{array}$ & $\begin{array}{l}\text { Octreotide } \\
100 \\
\mu g \times 3 / \text { day }\end{array}$ \\
\hline $\begin{array}{l}\text { Amino acid } \\
\text { infusions }\end{array}$ & $Y$ & Y & Y & Y & Y & $Y$ & Y \\
\hline Chemotherapy & N & N & $\mathrm{N}$ & N & $\begin{array}{l}\text { Sulfatinib; } \\
\text { Everolimus }\end{array}$ & $N$ & $\mathrm{~N}$ \\
\hline PRRT & N & N & $\mathrm{N}$ & $\begin{array}{l}\text { 90Y-DOTALAN } \\
200 \mathrm{mCi} \times 2\end{array}$ & $\mathrm{~N}$ & $N$ & $\mathrm{~N}$ \\
\hline $\begin{array}{l}\text { Other } \\
\text { treatments }\end{array}$ & N & $\mathrm{N}$ & N & TACE, RFA & TACE & N & $\mathrm{N}$ \\
\hline $\begin{array}{l}\text { Glucagon } \\
\text { after surgery } \\
(\mathrm{pg} / \mathrm{mL})\end{array}$ & 103 & 233 & ND & 816 & ND & 315 & 110 \\
\hline $\begin{array}{l}\text { Symptoms } \\
\text { improved }\end{array}$ & $\begin{array}{l}3 \text { days after } \\
\text { surgery }\end{array}$ & $\begin{array}{l}1 \text { week after } \\
\text { surgery }\end{array}$ & $\mathrm{N}$ & Y & $\begin{array}{l}1 \text { day after } \\
\text { surgery }\end{array}$ & $\begin{array}{l}3 \text { days after } \\
\text { surgery }\end{array}$ & $\begin{array}{l}1 \text { day after } \\
\text { surgery }\end{array}$ \\
\hline $\begin{array}{l}\text { Survival } \\
\text { (months) }\end{array}$ & Alive & $\begin{array}{l}\text { Alive (> } 5 \\
\text { years) }\end{array}$ & $\begin{array}{l}11 \text { ( } \\
\text { diagnosis) } \\
13 \text { (first } \\
\text { symptom) }\end{array}$ & $\begin{array}{l}63 \text { (diagnosis) } \\
78 \text { (first } \\
\text { symptom) }\end{array}$ & $\begin{array}{l}156 \text { (diagnosis) } \\
168 \text { (first } \\
\text { symptom) }\end{array}$ & Alive & Alive \\
\hline $\begin{array}{l}\text { Normal glucagc } \\
\text { PPPD, robotass } \\
\text { transarterial ch } \\
\text { available. }\end{array}$ & $\begin{array}{l}\text { levels }<200 \mathrm{pc} \\
\text { ted pylorus-pre } \\
\text { noembolization }\end{array}$ & $\begin{array}{l}\text { hL. NME, nec } \\
\text { ving pancrea } \\
\text { RRT peptide }\end{array}$ & $\begin{array}{l}\text { zing migratory } \\
\text { duodenectomy } \\
\text { eptor radioligar }\end{array}$ & $\begin{array}{l}\text { ythema; DVT, dee } \\
\text { DP, distal pancrea } \\
\text { therapy; RFA, rad }\end{array}$ & $\begin{array}{l}\text { ein thrombosis; I } \\
\text { tomy; PD, pancre } \\
\text { equency ablation }\end{array}$ & $\begin{array}{l}\text { impaired glucose } \\
\text { coduodenectomy } \\
\text {, no; Y, yes; ND, no }\end{array}$ & $\begin{array}{l}\text { lerance; R- } \\
\text { ACE, } \\
\text { done; NA, not }\end{array}$ \\
\hline
\end{tabular}


NME was the first symptom in all the patients (Figure 1). One patient presented with repeated stomatitis, atrophic glossitis along with erythema as the first symptom. All the patients reported in this study had a delayed diagnosis. All the patients (7/7) visited the dermatology department first with a complaint of pruritic and painful polymorphic rash affecting of several months' duration. The rash initially appeared at different places such as extremities, faces, ankles, gluteal regions, perineum, groins, lower back or abdomens. Then the erythema slowly progressed throughout the body. The boundary of rash is not clear and part of the lesions are fused in large areas. Erosion, exudation and necrosis can be seen in the center of some erythema. Topical steroids treatment led to a temporary improvement of the erythema in 6 of 7 patients, but it still occurred repeatedly and the erythema reoccurred accompanied by even much severer pruritus and pain. There was only patient who was treated with topical steroids but without any clinical improvement.

While not all of the patients initially had diabetes, all of the patients eventually developed diabetes (5/7) or IGT (2/7). Other symptoms included stomatitis and glossitis (2/7), weight loss (4/7), anemia (4/7), diarrhea (1/7), DVT (1/7) (Table 1). Among these symptoms, NME and diabetes or IGT were present in all the patients and may be considered tumor-specific symptoms.

\section{Examinations and disease diagnosis}

Skin biopsies were performed in all seven cases, and NME was diagnosed by the pathologist in all cases. Serum plasma glucagon level was significantly elevated (range $217-3155 \mathrm{pg} / \mathrm{mL}$; normal $<200 \mathrm{pg} / \mathrm{mL}$ ) in all patients before surgery. Other biochemical abnormalities are outlined in Table 1.

Upon diagnosis, the primary tumors were identified by abdominal enhanced computed tomography (CT) in 4 of 7 cases, and by magnetic resonance imaging (MRI) in 3 of 7 cases in our patient cohort. Other modalities used for diagnosis were ultrasonography (3/7), liver metastasis biopsy (2/7), laparoscopic pancreatic biopsy (3/6) and skin biopsy (7/7). All patients had histopathological confirmation of the neuroendocrine tumor.

Four tumors were located in the head of the pancreas, two tumors were located in the tail, and one was located in the body and tail of the pancreas. Four patients presented with hepatic metastases upon diagnosis and two cases were found liver and lymph nodes metastases. Initial tumor stage, size, sites of metastasis, pathologic characteristics and proliferation index are detailed in Table 1. Other lymph nodes metastatic foci were found in two patients (patient 5 and 6) (Table1).

\section{Therapy}

The available treatment modalities used in our patients and the overall response to treatment are presented in Tables 1 . Six of seven cases received surgical resection (5 in our hospital, 1 in other hospital), involving pancreaticoduodenectomy (PD) (4/6) and distal pancreatectomy (DP) $(2 / 6)$. Of the 4 patients who received PD and the 2 patients who received DP, 1 patient each also received combined hepatic metastasectomy (Table 1). For all the 6 patients received surgery, the skin lesions improved gradually within 3 days after the surgery and postoperative plasma glucagon levels sharply decreased or even back to normal levels. One patient (patient 3) did not undergo surgical resection and was only treated with somatostatin analogues because multiple liver metastases had been found at diagnosis. All the 7 patients received somatostatin analogue and amino acid infusions. Four of seven patients received octreotide LAR and the other 3 of 7 patients got octreotide treatment. Patient 4 also undergone transarterial chemoembolization (TACE), radiofrequency ablation (RFA) and 90Y-DOTALAN due to liver metastasis. Patient 5 received chemotherapy (sulfatinib; everolimus) and TACE treatment.

\section{Pathological characteristics}

The primary tumor size ranged from $3.1 \times 2.3 \times 1.6 \mathrm{~cm}$ to $8.0 \times 5.0 \times 3.5 \mathrm{~cm}$. Metastases were found in three of the six patients during surgery. Pathologists diagnosed patient 4 with poorly differentiated pancreatic islet cell tumors, and other diagnosed patients with moderate differentiated pancreatic islet cell tumors. Immunohistochemistry confirmed the final diagnosis of glucagonoma. The Ki-67 index was $8-10 \%$ for patient 1,2,3,5 and 7,30\% for patient 6 , and was not tested in the patient 4 . Other immunohistochemical stainings for chromogranin $A$ (CgA), synaptophysin (Syn) and somatostatin receptor 2 (SSTR2) were also included (Figure 2). In summary, 5 patients had had a grade 2 (G2) tumor, and patient 6 had a grade 3 (G3) tumor.

\section{Follow-up}

By the time of follow-up in October 2021, three out of seven patients had died and all the deaths were disease related. The mean time to diseaserelated death was 6.4 years (range $0.9-13$ ) from diagnosis and 7.2 years (range 1.1-14) from initial clinical manifestations. 


\section{Discussion}

Neuroendocrine tumors of the pancreas (pNETs) are rare, with an annual incidence of less than $0.8 / 100,000[8]$. They include both functioning and non-functioning pNETs and are mostly slowly growing with a capacity to metastasize. The functioning pNETs constitute about $30-40 \%$ of all pNETs displaying different clinical syndromes due to hormone over-secretion by the tumor, such as excess gastrin (gastrinoma, ZollingerEllison syndrome), insulin (insulinoma), glucagon (glucagonoma), somatostatin (somatostatinoma) and vasoactive intestinal peptide (VIPoma). While the symptoms of non-functioning pNETs are mainly secondary to local mass effect of the tumor, such as abdominal pain, jaundice, weight loss and so on[9].

Glucagonomas is an extremely rare pNETs, with an estimated global incidence of one in 20 million people[7]. The average age at diagnosis for glucagonoma is 53.5 years, affecting men and women in almost equal proportions $[7,10]$. However, all the patients in our cohort are female, with an average age of 42.5 years. Most tumors are sporadic, while less than $3 \%$ of tumors are associated with multiple endocrine neoplasia type 1 (MEN1), one of the most common familial cancer syndromes[11]. In approximately $87 \%$ of cases, the glucagonoma is located in the tail of the pancreas. Over $50 \%$ are metastatic at the time of diagnosis[12] which highlights the importance of early diagnosis of the disease.

The classic features of glucagonoma syndrome include a characteristic rash named NME, IGT or DM, DVT, depression, anemia, weight loss, hypoaminoacidemia and low zinc levels[1, 13-14]. NME is usually the first clinical manifestation of glucagonoma syndrome, which often starts as pruritic and painful erythema and gradually enlarge and coalesce to form bullous lesions [15]. The pathogenesis of NME is still uncertain. Hyperglucagonemia might lead an important role, as surgical removal of glucagonomas or stabilizing glucagon levels using somatostatin analogue results in rash controlling $[7,16]$. Other theories including hypoaminoacidaemia-induced epidermal protein and micro-nutrient depletion, deficiency of essential fatty acids and zinc should also be considered because nutritional support therapy and topical zinc therapy has been used to ameliorate NME[17-18].

Surgical removal is considered the only definitive and curative treatment for pancreatic glucagonoma and NME[7]. Optional operations include simple enucleation $(<2 \mathrm{~cm}$ ) with peripancreatic lymph dissection, pancreaticoduodenectomy with peripancreatic lymph dissection, distal pancreatectomy with peripancreatic lymph dissection and splenectomy. However, more than half of all glucagonomas present with a metastatic disease, most commonly liver metastasis. It has reported that synchronous resection of pancreatic neuroendocrine tumor and liver metastasis (more than $30 \%$ of the liver tissue retained) provides a more favorable outcome[19]. Liver transplantation may be considered as a potential therapeutic approach for unresectable hepatic metastases arising from pancreatic glucagonoma[20].TACE might also be a safe therapeutic approach for liver metastasis arising from pNETs because of highly vascular and blood supply that primarily derive from the hepatic artery[21]. In addition, RFA usually performed in combination with surgery, which has certain advantages to remove isolated metastases[22]. The medical therapy of glucagonoma including chemotherapeutics, somatostatin analogue, PRRT and molecular targeted drugs are also effective in controlling the clinical symptoms and tumor growth $[7,16]$.

In conclusion, glucagonoma is a rare type of functional pNET. Since NME might be the only clue for the early detection of this tumor, it is very important to correct and timely diagnosis of NME. Currently, surgical intervention is the only definitive treatment for this disease. Medical therapy is effective for symptom controlling and metastatic disease management.

\section{Declarations}

\section{Conflict of interest statement:}

The authors declare that they have no conflict of interest.

\section{Funding resources}

The present study was supported by grant the Natural Science Basic Research Project of Shaanxi Province (grant no. 2020JM-367).

\section{Author contribution:}

Design of the work: Zheng Wu, Zheng Wang

Acquisition, analysis, or interpretation of data for the work: Wei Li, Xue Yang Drafting the work or revising it critically for important intellectual content: Yuan Deng, Yina Jiang, Guiping Xu, Enxiao Li, Yinying Wu, Juan Ren, Zhenhua Ma, Shunbin Dong, Liang Han

Final approval of the version to be published: all the authors

\section{References}


1. Cunha-Silva M, da Costa J G, Faria G A S, et al. Diarrhea: a missed D in the 4D glucagonoma syndrome. Autops Case Rep. 2019. 9 (4): e2019129.

2. Daly D M, Thompson B, Low J, et al. Emergency pancreatic resection for glucagonoma associated with severe necrolytic migratory erythema. ANZ J Surg. 2019. 89 (5): 599-602.

3. Eldor R, Glaser B, Fraenkel M, et al. Glucagonoma and the glucagonoma syndrome -cumulative experience with an elusive endocrine tumour. Clin Endocrinol (Oxf). 2011. 74 (5): 593-8.

4. Kawsar H I, Habib A, Saeed A. Unremitting chronic skin lesions: a case of delayed diagnosis of glucagonoma. J Community Hosp Intern Med Perspect. 2019. 9 (5): 425-29.

5. van Beek A P, de Haas E R, van Vloten W A, et al. The glucagonoma syndrome and necrolytic migratory erythema: a clinical review. Eur J Endocrinol. 2004. 151 (5): 531-7.

6. Krampitz G W, Norton J A. Pancreatic neuroendocrine tumors. Curr Probl Surg. 2013. 50 (11): -45.

7. John A M, Schwartz R A. Glucagonoma syndrome: a review and update on treatment. J Eur Acad Dermatol Venereol. 2016. 30 (12): $2016-$ 22.

8. Dasari A, Shen C, Halperin D, et al. Trends in the Incidence, Prevalence, and Survival Outcomes in Patients With Neuroendocrine Tumors in the United States. JAMA Oncol. 2017. 3 (10): 1335-42.

9. Akirov A, Larouche V, Alshehri S, et al. Treatment Options for Pancreatic Neuroendocrine Tumors. Cancers (Basel). 2019.11 (6).

10. Wu S L, Bai J G, Xu J, et al. Necrolytic migratory erythema as the first manifestation of pancreatic neuroendocrine tumor. World J Surg Oncol. 2014. 12220.

11. Sadowski S M, Triponez F. Management of pancreatic neuroendocrine tumors in patients with MEN 1. Gland Surg. 2015.4 (1): $63-8$.

12. Cardoso Filho Fde A, Feitosa R G, Fechine C O, et al. Glucagonoma syndrome associated with necrolytic migratory erythema. Rev Assoc Med Bras (1992). 2015. 61 (3): 203-6.

13. Al-Faouri A, Ajarma K, Alghazawi S, et al. Glucagonoma and Glucagonoma Syndrome: A Case Report with Review of Recent Advances in Management. Case Rep Surg. 2016. 20161484089.

14. Wei J, Song X, Liu X, et al. Glucagonoma and Glucagonoma Syndrome: One Center's Experience of Six Cases. J Pancreat Cancer. 2018. 4 (1): $11-16$

15. Boujan N, Geraud C. Neuropsychiatric symptoms, skin disease, and weight loss: necrolytic migratory erythema and a glucagonoma. Lancet. 2020. 395 (10228): 985.

16. Gut P, Waligorska-Stachura J, Czarnywojtek A, et al. Management of the hormonal syndrome of neuroendocrine tumors. Arch Med Sci. 2017. 13 (3): 515-24.

17. He S, Zeng W, Geng S, et al. Glucagonoma syndrome with atypical necrolytic migratory erythema. Indian J Dermatol Venereol Leprol. 2019.

18. Ogawa Y, Kinoshita M, Shimada S, et al. Zinc and Skin Disorders. Nutrients. 2018. 10 (2).

19. Gaujoux S, Gonen M, Tang L, et al. Synchronous resection of primary and liver metastases for neuroendocrine tumors. Ann Surg Oncol. 2012. 19 (13): 4270-7.

20. Radny P, Eigentler T K, Soennichsen K, et al. Metastatic glucagonoma: treatment with liver transplantation. J Am Acad Dermatol. 2006. 54 (2): 344-7.

21. Kennedy A S. Hepatic-directed Therapies in Patients with Neuroendocrine Tumors. Hematol Oncol Clin North Am. 2016.30 (1): $193-207$.

22. Oberg K. Management of functional neuroendocrine tumors of the pancreas. Gland Surg. 2018. 7 (1): 20-27.

\section{Figures}

\section{Figure 1}

Skin lesions of glucagonoma.

\section{Figure 2}

Immunohistochemical staining positive for glucagon, Cga, Syn and SSTR2. 